\title{
ESTUDIOS
}

\section{La flauta traversa del Nuevo Mundo surgió en Tiwanaku 1}

\author{
In the New World the Transverse Flute \\ originated in Tiwanaku
}

\author{
por \\ Rafael Francisco Díaz S. \\ Instituto de Música \\ Pontificia Universidad Católica de Chile, Chile \\ rdiazs@uc.cl
}

Este artículo aporta antecedentes para demostrar que el aerófono conocido como flauta traversa no es exclusivo de Europa, sino que América del Sur también produjo un modelo genuino que proviene de la cultura Tiwanaku. Esta cultura, entre el 500 y el 900 d.C., habría generado una flauta traversa y la habría exportado hacia los territorios vecinos (especialmente el oasis de San Pedro de Atacama). Los ejemplares preservados en los museos precolombinos de Sudamérica demuestran que el modelo de pífano militar europeo determina la organología de las flautas traversas más antiguas de Sudamérica, excepto en el caso del aerófono travesero de Tiwanaku, el único ejemplar aparecido hasta ahora en condiciones de estudio. Por lo tanto, este último contradice el canon europeo y representa un tipo de flauta traversa genuino de la América del Sur precolombina.

Palabras clave: Tiwanaku, flauta traversa, pífano militar, cultura precolombina, canon.

The thesis put forward in this article is that the transverse flute did not originate in Europe only. In the Pre-Columbian Tiwanaku culture located in South America a flute prototype was also developed between 500 and 900 a.C. and exported to neighboring territories, particularly the San Pedro de Atacama oasis. This article intends to prove that the Tiwanaku flute collected by the jesuit priest Gustavo Le Paige and deposited at the San Pedro de Atacama Arqueological Museum is so far the only example of an American flute that did not derive from the canon of the European military whistle. The oldest American transverse flutes preserved at South American museums which are in conditions to be studied derive in its entirety from the canon of the European military whistle. Therefore the Tiwanaku flute can be considered a type of flute which genuinely belongs to Pre-Columbian South America.

Key words: Tiwanaku, transverge flute, military whistle, Pre-columbian culture; canon.

1 Investigación financiada por el Centro Interdisciplinario de Estudios Interculturales e Indígenas, ICIIS, código de proyecto CONICYT/FONDAP/15110006, del cual el autor es investigador asociado, y por el proyecto FONDECYT REGULAR 1110027, "El imaginario aborigen de la música chilena indigenista", del cual el autor es el investigador responsable.

Revista Musical Chilena, Año LXVII, enero-junio, 2013, No 219, pp. 12-41 


\section{INTRODUCCIÓN}

Este trabajo pretende demostrar que el aerófono conocido como flauta traversa o travesera no es exclusivo de Europa, sino que América del Sur también produjo un modelo genuino que proviene de la cultura Tiwanaku. Esta cultura, entre el 500 y el 900 d.C., habría generado este tipo de aerófono con su correspondiente unidad cultural performática, adscrita a la ejecución del instrumento, y lo habría exportado hacia los territorios vecinos, especialmente la alta puna del sector de San Pedro de Atacama, hoy conocida como región cultural del Alto Loa en el norte de Chile. La flauta traversa de Tiwanaku llegó al oasis de San Pedro de Atacama como souveniry/o ofrenda a los señores atacameños o como el instrumento requerido por shamanes que lo habrían obtenido por trueque. El actual "pífano travesero", hoy utilizado en la mayoría de las fiestas patronales de Perú, Bolivia, Ecuador y norte de Chile, no corresponde a la flauta traversa Tiwanaku. Corresponde al pito militar travesero traído por los españoles y que fue replicado por las cofradías del cono sur sudamericano, en desmedro de la flauta Tiwanaku, por razones multifactoriales, entre otras, el decaimiento de la práctica del shamanismo y la desaparición del arte de luthería para este instrumento que implicaba características sofisticadas de fabricación en comparación con el pífano travesero español. Debido a que las evidencias de los museos precolombinos de Sudamérica muestran que el modelo canónico tipo pífano militar europeo determina la organología de las flautas traversas más antiguas del cono sur, se puede colegir que el modelo de flauta traversa de Tiwanaku es el único ejemplar en condiciones de estudio que contradice este canon y que representa a un tipo de flauta traversa genuino de la América del Sur precolombina.

\section{EL (DES)CUBRIMIENTO DE LA FLAUTA TRAVERSA DEL NUEVO SUR DEL MUNDO}

Por casi un siglo la teoría etno-organológica ha negado la posibilidad de la existencia de la flauta traversa prehispánica meso y sudamericana (Nordenskiöld 1924: 192). Raoul y Marguerite D'Harcourt apoyan esta teoría, afirmando que “(...) en el imperio incaico, la flauta traversa no es mencionada en ninguna parte. La encontramos más al norte, en California, donde se fabricaba a partir de los huesos del pelícano y similares (...). Este simple procedimiento de fabricación escapó a los quechuas y a los yungas" (1990: 60).

Sin embargo, en 1969 fue desenterrado por el sacerdote belga Gustavo Le Paige ${ }^{2}$ el instrumento que he llamado "flauta Tiwanaku". El instrumento fue encontrado en buenas condiciones de preservación gracias a la sequedad del territorio desértico.

2 El sacerdote jesuita Gustavo Le Paige (1903-1980), de nacionalidad belga, llegó a Chile en 1953 destinado por la Compañía de Jesús al mineral de Chuquicamata, II Región de Chile. En 1955 se estableció en el pueblo de San Pedro de Atacama para desempeñar la función de párroco del lugar. Desde entonces realizó una intensa actividad como arqueólogo, en cuya disciplina tenía una formación autodidacta. En 1958 fundó el Museo Arqueológico San Pedro de Atacama (MASPA), lugar en el que pudo guardar las piezas que desenterró de tumbas prehispánicas en la zona llamada Alto Loa, en la región de Antofagasta, al norte de Chile. Falleció en Santiago de Chile en 1980. 
Este instrumento es mencionado por María Ester Grebe en su artículo "Instrumentos musicales precolombinos de Chile" (1974). Por la amplitud de su universo de estudio, solo se limita a escribir que el instrumento es de origen incaico y fabricado de caña. Agrega unas dimensiones inexactas de la longitud del tubo y nada respecto de las dimensiones del diámetro de los agujeros y otras especificidades fundamentales. Se trataba de una etnomusicología de catastro y el detalle no era importante. Luego en los ochenta, el instrumento se exhibió en Santiago de Chile en una exposición del Museo Chileno de Arte Precolombino. Las notas de catálogo acerca del instrumento se limitan a indicar la cantidad de agujeros de la flauta, a citar el museo de procedencia y el número de catalogación de Le Paige (Pérez de Arce 1982). La leyenda del catálogo dice: "está hecha con un trozo de madera partido longitudinalmente y ahuecado. Luego se unían las dos mitades con amarras de cuero o lana y se ponía un tapón en el extremo de la embocadura. No suena. $370 \mathrm{~mm}$ " (1982). Por cierto la información es casi totalmente equivocada, salvo el hecho de que está fabricada de madera. Sin embargo, no indica qué madera es y cómo se llegó a colegir esa información. No cabe duda de que es una conclusión meramente basada en la suposición. En realidad el instrumento nunca fue deliberadamente partido en dos, ahuecado y luego unido nuevamente. El instrumento fue pisado por alguien o roto accidentalmente. Luego fue unido con ocho amarres de hilo de coser moderno de color ocre. No suena porque el instrumento fue seriamente dañado (ver Figura 1).

\section{FIGURA 1}

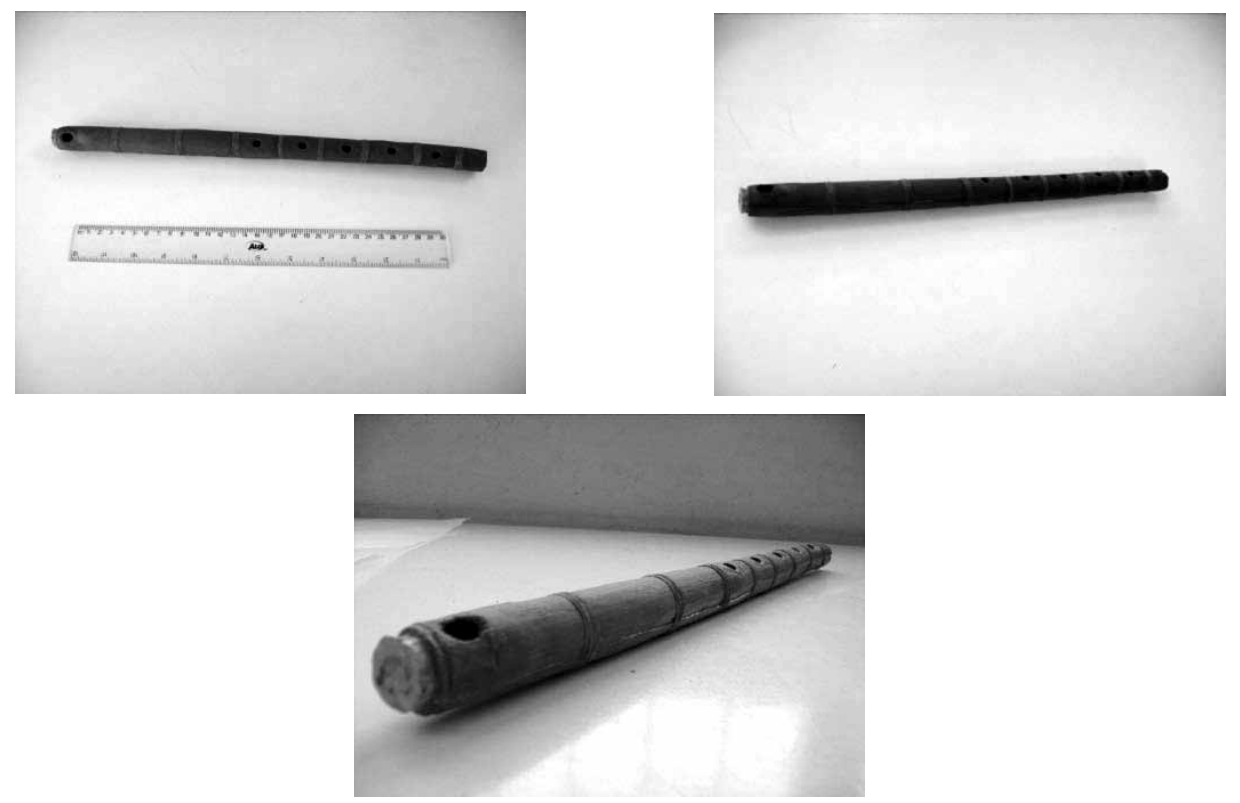

Fotos tomadas por el autor de este texto del ejemplar original de la flauta traversa Tiwanaku. Museo Arqueológico San Pedro de Atacama, Chile (02/11/2011). 
El hallazgo de la flauta traversa de Tiwanaku se produjo en excavaciones realizadas entre el 30 de agosto y el 9 de septiembre de 1969. Estas excavaciones fueron realizadas en una comuna del oasis de San Pedro de Atacama ${ }^{3}$ llamado "Coyo Oriental Sur". Las notas del cuaderno de campo del padre Le Paige dicen:

\section{Registro 4089}

"Coyo Oriental Sur: del 30 de agosto al 9 de septiembre del 69.

Sin cráneo en tumba no destrozada. Un arco entero con palos de flechas, una cerámica negra casi pulida, un martillo de piedra pintado de verde con mango doble, cuatro canastas que serían cesterías, una flauta de cinco "hoyitos", una bolsa de hilo, una cabeza y hueso de llama"4.

Este es el primer indicio de la flauta traversa de Tiwanaku. En términos del padre Le Paige, "una flauta de cinco hoyitos". Su poca experiencia en el campo de la organología musical precolombina lo llevó a obviar este hallazgo. Sin embargo, su acuciosa descripción de los objetos encontrados en el "gentilario" 5 nos permite colegir la banda cronológica en la que la flauta Tiwanaku se encuentra ubicada. La data cronológica de tipo ceramológico muchas veces es tan importante como las medidas químicas de C-14. Es por eso que nos detenemos en el análisis de las notas del padre Le Paige.

Junto con la asistente de conservación de muestras del Museo Arqueológico San Pedro de Atacama (MASPA), Srta. Jimena Cruz Mamani, emprendimos el análisis del contexto cultural de las notas del padre Le Paige.

\subsection{Análisis contextual de la nota de campo 4089 del padre Le Paige}

Coyo Oriental Sur: del 30 de agosto al 9 de septiembre del 69.

\section{Sin cráneo en tumba no destrozada...}

Hasta hoy, los gentilarios de San Pedro de Atacama quedan al descubierto por efectos de erosión causada por fuerzas eólicas, crecidas de ríos, lluvias y temporales del invierno boliviano. Así pues, "los cráneos afloran por erosión natural

3 San Pedro de Atacama es un oasis situado a 2400 metros sobre el nivel del mar, en el extremo norte de la cuenca del Salar de Atacama en la Segunda Región de Chile. Su centro lo constituye el pueblo homónimo, a $22^{\circ} 55^{\prime}$ latitud S y $68^{\circ} 12^{\prime}$ longitud W. Actualmente es el principal núcleo poblacional entre los varios pueblos que se ubican en la vertiente oriental del Salar de Atacama.

4 Notas del cuaderno de campo escritas por el padre Gustavo Le Paige, número de registro 4089.

5 Tumba de personas que fueron enterradas sin ser bautizadas en la fe católica. Se refiere a "gentiles" como todos aquellos habitantes de la región surandina que murieron en su creencia precolombina. Gentilario, por extensión, alude a tumbas precolombinas de la actual área atacameña. También "gentilare" significa lugar de tumba. Por último, los gentiles son los mayores, los precolombinos. La mitología moderna atacameña afirma que si un niño muere no bautizado es "un ángel no bautizado". Pasa a ser un duende que es un apoderado del diablo. 
debido a que los cuerpos son enterrados en posición fetal" 6 . También es posible que algunos personajes hayan sido decapitados por una causa ritual antes de ser enterrados. Incluso en Quitor han sido encontradas varias cabezas arrastradas desde gentilarios lejanos.

\section{Un arco entero con palos de flechas}

Personaje masculino, no necesariamente señor atacameño. En cambio las tabletas de rapé sí son asociables a personas de posición social elevada. Un arco con flechas no representa un símbolo de status aunque sí constituye una señal de nivel cultural superior.

una cerámica negra casi pulida...

Este hallazgo es posiblemente el más valioso. La cerámica negra casi pulida representa el momento peak de la cultura Tiwanaku y su datación está claramente determinada por Lautaro Núñez y otros: etapa Coyo, 500-900 d.C., etapa de esplendor de la cultura Tiwanaku que repercute directamente en el oasis de San Pedro de Atacama. En esta época "comienza una configuración de una identidad étnica muy marcada” (Núñez 2007: 51-52). La data inequívoca de la cerámica negra semipulida nos permite la certeza que la flauta encontrada en este gentilario tiene una antigüedad de contexto ceramológico bastante fiable.

\section{un martillo de piedra pintado de verde con mango doble...}

En la banda cronológica 500-900 d.C. de la puna atacameña, una herramienta de trabajo como parte del ajuar funerario representaba el oficio del difunto (Tarragó 1989). Un martillo, símbolo de trabajo fabricado con doble mango, debiera ser interpretado como una herramienta y, por lo tanto, como símbolo de un oficio. No debiera confundirse con un arma llamada "rompecabeza" (arma lítica con mango simple). A su vez, por esta época, los roles laborales estaban asignados. La extracción de cobre desde las galerías soterradas de Chuquicamata era una actividad plenamente establecida desde el 500 d.C. (Núñez 2007: 53). Se puede presumir que el difunto ejercía el rol de minero en la sociedad atacameña de la época. Un rol que no poseía status social elevado (Llagostera 2011).

\section{cuatro canastas que serían cesterías...}

Según el informante Timoteo Cruz Salvatierra, "las cestas portaban alimentos para que el difunto hiciera su viaje hacia la otra dimensión. También se mataba a un perro negro para que le sirviera como un guía; era para cruzar el río"7. Las vasijas

6 Observaciones surgidas del diálogo entre la asistente de conservación de muestras, Srta. Jimena Cruz Mamani y el autor de este artículo. MASPA. 3/11/2011.

7 Testimonio de Timoteo Cruz Salvatierra, padre de la asistente de conservación del MASPA, Jimena Cruz. 4/11/2011. Timoteo Cruz es descendiente de kunza (atacameño) por padre y madre. 
eran puestas en la tumba para hacer el viaje astral. Estas usualmente contenían un alucinógeno muy potente que era traído de la actual región argentina vecina a San Pedro cuya cultura era llamada Huaque. Las vasijas son otro elemento que lleva a pensar que el "gentil" era probablemente un shamán.

\section{una flauta de cinco "hoyitos"...}

Posiblemente un trueque o un obsequio. El oficio principal del difunto está determinado (minero). Sin embargo, la existencia de una flauta en su tumba refleja, por una parte, una praxis musical adscrita a la ritualidad ${ }^{8} \mathrm{y}$, a la vez, refleja el valor sentimental que poseía para el difunto el instrumento en sí. La práctica de un instrumento en esta banda cronológica y contexto cultural asigna a su cultor un rol especial dentro de la vida social atacameña. El carcaj de flechas junto a este instrumento musical son indicios de que el difunto poseía ciertas características singulares asociadas al $\operatorname{shaman}^{9}$. La proveniencia del instrumento pudo ser desde el centro cultural de Tiwanaku (al oeste de la actual La Paz) o ser el producto de un trueque entre el difunto y comerciantes de tribus caravaneras que conectaban la costa de la actual Antofagasta con la capital del imperio Tiwanaku (Berenguer 2004). El padre Le Paige no estaba en condiciones de aquilatar la importancia etnomusicológica de este instrumento. Afortunadamente su disciplina científica le hizo consignar el objeto y guardarlo en condiciones de conservación.

\section{una bolsa de hilo...}

Una bolsa de hilo, chuspa (quechua) significa bolsa contenedora de coca. Algunas de las bolsas encontradas en este gentilario tenían restos de cabello y uñas. Según Jimena Cruz, "los restos orgánicos son parte de uno y (por medio de ellos) podían hacer mal contra uno, por eso se guardaban en millos (quechua, bolitas de pelo)"10.

\footnotetext{
Sus nombres hispanos son un recurso de adaptación a la sociedad chilena. Posee un vasto saber de su cultura que le ha sido transmitido oralmente de generación en generación. Actualmente trabaja como auxiliar en el MASPA.

8 Los objetos y restos orgánicos que acompañan a la flauta constituyen un ajuar shamánico. Al respecto, consultar Isbell 2008 y Núñez 2007.

9 Shamán, palabra atribuida a un dialecto siberiano, ha terminado por describir a una persona que tiene la capacidad de entrar en estado de "éxtasis"; una especie de trance obtenido por medios físicos (flagelaciones, danzas, cantos, ejecuciones instrumentales, ayunos) o químicos (alucinógenos). En este estado alterado de conciencia pueden trasponer el umbral de los sentidos y acceder a dimensiones que trascienden la realidad sensorial. Para alcanzar este estadio, el shamán se transmuta en algún animal tutelar. Los shamanes son "escogidos" por un destino superior y no tiene que ver la voluntad propia para acceder a tal condición. Sí deben someterse a un riguroso proceso de aprendizaje con un maestro que potencie sus dones naturales. También Berenguer (2000) le da importancia al rol de los shamanes, porque es muy probable que ellos hubiesen sido los intermediarios entre la gente y los dioses y llegaran a ser imprescindibles para la sociedad. Los templos eran los lugares donde los shamanes entraban en trance. Esto incluía danzas, cantos y sonidos que activaban a las fuerzas sobrenaturales para atraer a los espíritus benignos y alejar a los malignos. "El trance era inducido por fuertes sustancias intoxicantes e incluía dramáticas transformaciones” (Berenguer 2000: 31).

10 Observación de Jimena Cruz Mamani, asistente de conservación del MASPA, 4/11/2011.
} 


\section{una cabeza y hueso de llama...}

Cabeza y hueso de llama: es una ofrenda exclusiva, probablemente se sacrificó la llama completa y tal vez más de una llama. Los restos de este camélido poseen una disposición especial en la tumba. Una llama caravanera o llama simple. Este dato es importante, pues estamos en presencia de un viajero. El gentil era un personaje especial, no solo un minero, pudo ser un curaca11, un shamán ${ }^{12}$ (ver Figura 2).

\section{FIGURA 2}
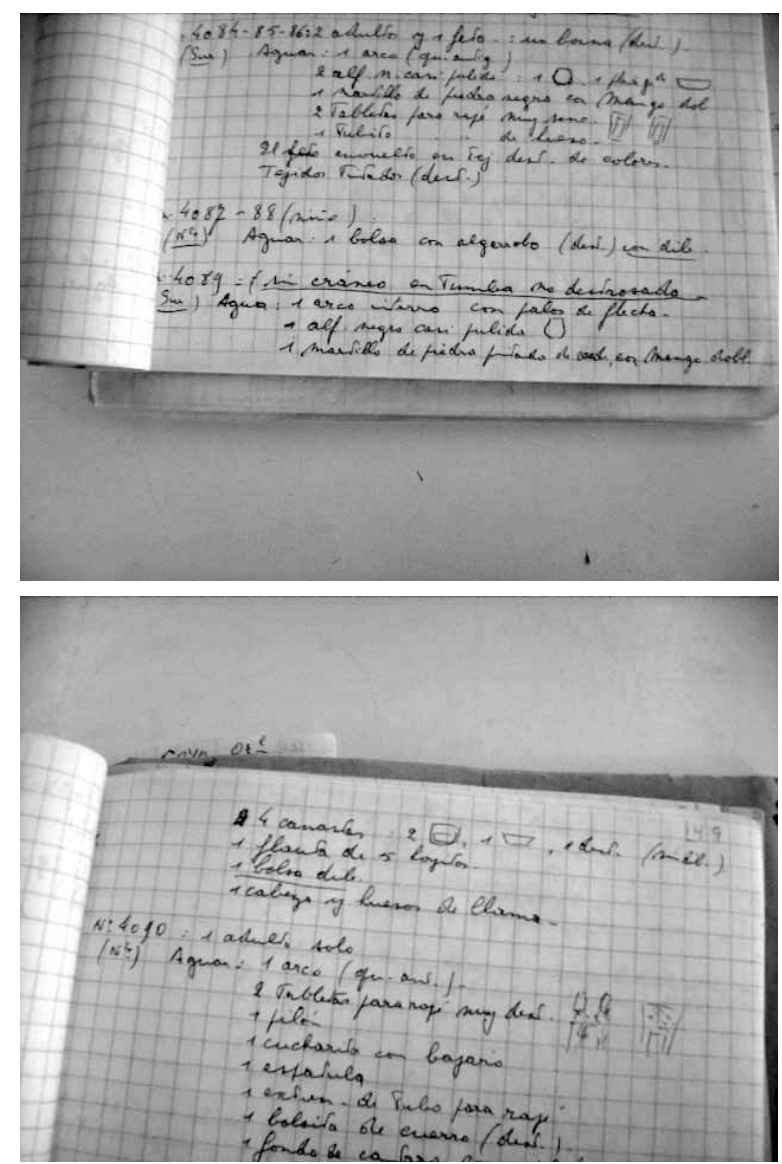

Fotografías del cuaderno de campo del padre Le Paige en donde consigna el hallazgo, entre otros objetos, de la flauta traversa de cinco agujeros. Fotos del autor. MASPA (04/11/2011).

11 Curaca, cacique o principal de la aldea. También puede aludir a un jefe tribal.

12 Observación del informante Tomás Cruz López, auxiliar de excavación del padre Le Paige y actual funcionario del MASPA, 4/11/2011. 


\section{ORIGEN}

San Pedro de Atacama se ha distribuido tradicionalmente en ayllus ${ }^{13}$. De norte a sur del pueblo los ayllus reciben los nombres de Catarpe, Quitor, Conde Duque, Solcor, Yaye, Larache, Tchecar, Sequiror, Vilama, Solor, Cucuter, Poconche, Beter, Coyo y Tulor. De todos ellos, Coyo es el ayllu que nos preocupa porque fue ahí donde apareció la flauta Tiwanaku. Coyo Oriente fue bautizado así por Le Paige en 1972. Este sitio entregó 160 tumbas (Llagostera y Costa 1999: 184). Le Paige señala que "58 de estas tumbas se pueden asignar a los períodos II y III y las demás, menos una, al período IV, con concho de vino o violáceo, pero con pocos ejemplares" (Le Paige 1964: 103) ${ }^{14}$. Esa tumba que Le Paige señala "como menos una" es Coyo Oriente 1 y se encuentra en el período V, que equivale a la Fase V de Tarragó ${ }^{15}$ (ver Figura 3).

La Fase V o Fase Coyo fue ubicada cronológicamente entre el 700-950 d.C., fundamentalmente mediante un análisis ceramológico ${ }^{16}$ y de contexto cultural (Llagostera y Costa 1999: 198). Afortunadamente en 1992 Oakland aportó dataciones radiocarbónicas para el sitio 1 de Coyo Oriente de 639 a 910 d.C. (Oakland 1992), por lo que necesariamente es preciso rebajar el inicio cultural de la fase V hacia el 500 d.C. con un umbral en el 900 d.C. (Llagostera y Costa 1999: 198). Esta fase Coyo (o fase V según Tarragó) se caracteriza por la influencia cultural de Tiwanaku (Núñez 2004). Tanto es así que a partir del 500 d.C. se detecta un ingreso paulatino de objetos tiwanakotas (Llagostera y Costa 1999: 198). A su vez, es una fase de marcada inflexión en la tecnología, en las costumbres y en las creencias del oasis de San Pedro por parte de Tiwanaku (Tarragó 1989). En los ajuares funerarios se observa una mayor complejidad cultural así como evidencias de una organización sociopolítica en torno a jefes-shamanes (1989). La influencia de Tiwanaku afectó profundamente el artefactual y así lo registra la modificación

13 Ayllu en lengua kunza puede ser traducida como oasis. Hoy tiene la connotación de distrito. Ayllus son por lo tanto los distintos distritos o comunas que conforman el perímetro del actual San Pedro de Atacama.

14 Las fases de ocupación en San Pedro se establecen, según Myriam Tarragó, a base de las características ceramológicas de los sitios arqueológicos. En especial, la fase o período II (fase Toconao) está representada por cerámica de cántaros antropomórficos negros o rojizos y combinados con vasijas rojizas. Está datada entre el 500 a.C.-100 d.C. La fase III, caracterizada por la tradición cerámica negra pulida, está datada entre el 100 d.C.-400 d.C. La fase o período IV la caracteriza la alfarería negra pulida y en un grado menor se combinan cuencos negros y rojos grabados .La data de este período es 400 d.C.-700 d.C. (Tarragó 1989)

15 En la fase $\mathrm{V}$ se produce el tránsito de la alfarería negra bruñida clásica a la gris plomiza de paredes gruesas y de menor brillo (Llagostera y Costa 1999: 194). Esta última clase de cerámica (gris plomiza) corresponde a la cerámica que Le Paige llama "semipulida", que fue encontrada en el gentilario "Coyo Oriente 1", donde apareció la flauta Tiwanaku, y que caracteriza al período de mayor influencia de esta cultura en el Oasis de San Pedro de Atacama (Núñez 2007: 51)

16 "Las prospecciones y el análisis ceramológico por distrito han permitido reconstruir la distribución sincrónica y las secuencias diacrónicas de los asentamientos, como un intento preliminar de conocer la ocupación y la dinámica del desarrollo sociocultural en el oasis de San Pedro de Atacama" (Llagostera y Costa 2009: 175). 
total de la técnica y el estilo de la alfarería ${ }^{17}$. La aparición de la flauta Tiwanaku en un gentilario de Coyo Oriente acompañada de vasijas de cerámica negra casi pulida fue el primer dato concreto respecto de la data y al origen del instrumento. Luego, el examen radiocarbónico de Oakland confirma la banda cronológica 639-910 d.C. Es notable observar la concordancia entre la data científica de penetración profunda de Tiwanaku en San Pedro y la influencia de las prácticas religiosas originarias del imperio en el oasis. Resulta lógico que el prestigio de la práctica shamánica haya desencadenado directamente la necesidad de un instrumento musical que sirviera como medio físico para inducir estados tránsicos ${ }^{18}$. El prestigio social de esta práctica en San Pedro lo refrendan los objetos rituales encontrados en los ajuares de los gentilarios de Coyo Oriente.

\section{FIGURA 3}

DISTRIBUCIÓN DE CEMENTERIOS CORRESPONDIENTES A LA FASE V (FASE COYO) DE SAN PEDRO DE ATACAMA

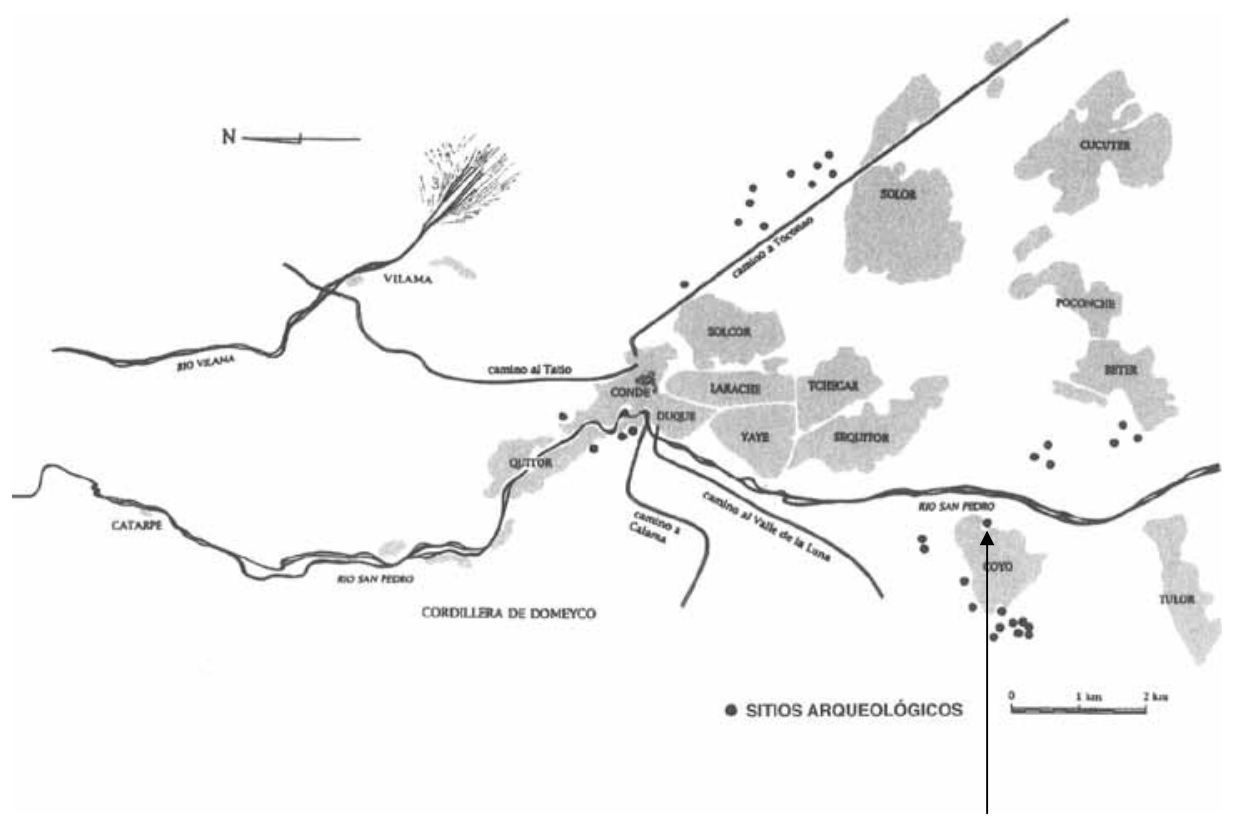

El punto negro marcado por la flecha (parte inferior derecha del diagrama) corresponde al lugar donde fue desenterrada la flauta Tiwanaku en 1969 (Coyo 1 Oriental).

17 Cerámica "gris pulida gruesa" según Tarragó o "negra casi pulida” según Le Paige. El término "artefactual" alude a manufacturas de uso ritual que guardan relación con objetos de uso artístico.

18 El término "tránsico" se refiere fundamentalmente a una situación catártica de tránsito a otro estado de conciencia. 


\section{MORFOLOGÍA DE LA FLAUTA TRAVERSA HALLADA EN EL MUSEO ARQUEOLÓGICO SAN PEDRO DE ATACAMA}

Actualmente existe solo un ejemplar de flauta traversa en el MASPA. Más aún, un aerófono de estas características no existe en ninguna colección de museo o archivo precolombino en Sudamérica. Las características morfológicas de este ejemplar son las siguientes:

a) El tubo está conformado hipotéticamente por dos piezas ${ }^{19}$. Está restaurado de modo rudimentario, pues está cortado longitudinalmente en forma irregular. Las dos partes están unidas por 8 amarras de un hilo de coser moderno de color ocre, que, eventualmente, sustituyen a los tendones o cuerdas de cuero que alguna vez unieron las dos partes. El ejemplar estudiado está muy mal reparado con cola fría y posee un corcho moderno como tapón en el extremo superior del tubo. Este corcho obstruye en parte el agujero del bisel o embocadura. El reparado imperfecto hizo imposible obtener sonidos en la exposición de 1982 en el Museo Chileno de Arte Precolombino.

b) El tubo está abierto en su extremo inferior y limpio de nervaduras en el interior.

c) El examen ocular hace imposible determinar si la materia orgánica que lo conforma es madera o caña. Las texturas de las maderas de la zona de San Pedro de Atacama (Chañar, Algarrobo, Pimiento, Tamarugo) no se corresponden con la textura del tubo. La identificación de la materia prima requerirá tecnología microscóspica (ver Figura 4).

\section{EJECUCIÓN DE LA FLAUTA DE TIWANAKU ORIGINARIA}

Gracias a un leve rebaje del corcho que obstruía parte de la embocadura e impedía el paso del aire al interior del tubo, se consiguió obtener sonidos de calidad no óptima del instrumento. Un flautista produjo sonidos eólicos (mitad aire mitad nota) en la gama escalar señalada en la Figura 5.

19 Hipótesis imposible de demostrar porque Le Paige no informa en qué condiciones encontró la flauta. Las posibilidades consideradas aceptables hoy son: la fabricación del instrumento partiendo en dos el tubo para limpiar el "alma" y luego unir ambos trozos con tendones de llamo o con amarras de cuero mojado, las que, al secarse, apretaban fuertemente las dos partes del tubo. La otra teoría es que el tubo estuviera hecho de una sola pieza con una madera especial que posibilitara esta modalidad de fabricación. Ambos procedimientos son utilizados por los luthiers contemporáneos de Bolivia, Perú y Chile. 


\section{FIGURA 4}

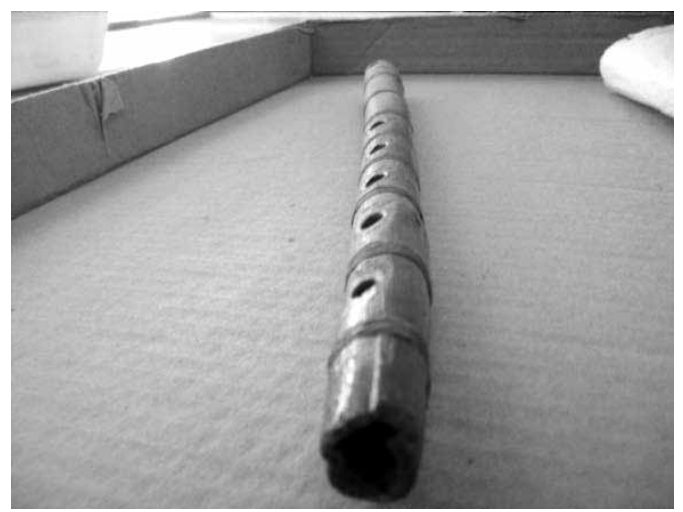

Foto tomada por el autor de este texto, del ejemplar original de la flauta traversa Tiwanaku. MASPA (05/11/2011).

\section{FIGURA 5}

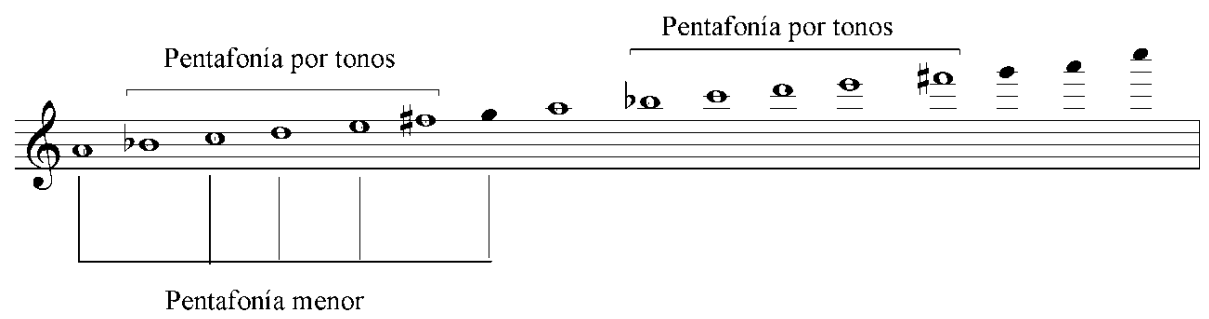

La serie completa de sonidos arriba graficada arrojó un doble sistema escalar: pentáfono por tonos/pentáfono menor. Esto, gracias a la acción de la nota Sib4 que posibilita "modular" al primer sistema escalar. La nota Sol5, marcada con cabeza negra sin plica, indica que es una nota de emisión forzada. Lo mismo las tres últimas notas del sistema escalar ${ }^{20}$.

Que el instrumento se sustentara en una escala pentáfona por tonos (ausente hoy en las fiestas patronales de Ecuador, Bolivia, Perú y Chile) significó una sorpresa mayor. Este hallazgo, de por sí significativo porque representa una modalidad idiomática desaparecida del área Surandina y Andes Centrales, obligó a un test de comprobación radical: reconstruir la flauta Tiwanaku en condiciones

20 Obviamente estas notas se encuentran en un sistema no temperado. Específicamente, el La4 de este sistema escalar se encuentra afinado en $429 \mathrm{~Hz}$. 
técnicas óptimas para poder confirmar la sonoridad que el modelo original parecía producir.

\section{RECONSTRUCCIÓN DE LA FLAUTA TIWANAKU}

La construcción de la réplica de la flauta Tiwanaku a partir del original contó con el apoyo de un luthier especializado en aerófonos. La verificación de su materia orgánica la realizó un biólogo, que apoyó en la interpretación de la estructura celular de la muestra, y un ingeniero bioquímico que analizó el registro de microscopia de barrido ${ }^{21}$. El análisis fue hecho a partir de una pequeña astilla de la flauta y permitió discernir en el $90 \%$ de probabilidad el tipo de materia orgánica con la que fue fabricada la flauta encontrada por el padre Le Paige. El ingeniero Jaime Emeres explica la técnica de microscopia de barrido en los siguientes términos:

"La microscopia de barrido explora la superficie de la muestra punto a punto (...) Su funcionamiento se basa en recorrer el objeto en cuestión con un haz muy concentrado de electrones, de forma parecida al barrido de un haz de electrones por la pantalla de una televisión. Esta técnica es ampliamente utilizada en la biología celular, permite apreciar con mayor facilidad texturas y objetos en tres dimensiones de pequeñas muestras. Los microscopios electrónicos solo pueden ofrecer imágenes en blanco y negro puesto que no utilizan la luz. Para el objetivo de esta investigación optamos por esta técnica, porque nos entregará información morfológica de la materia analizada y extraer muchas de sus características a través del análisis de las imágenes obtenidas" 22 .

En lo concreto, la imagen del microscopio de barrido aplicado a la astilla de la flauta Tiwanaku permitió al equipo de especialistas realizar un análisis morfológico y fractológico; un análisis de la corrosión de superficies y oxidaciones del tejido; una cartografía de los elementos químicos presentes en la astilla; espesores y distribución de capas del tejido (ver Figura 6a).

21 El microscopio electrónico de barrido es un instrumento capaz de proporcionar un amplio rango de información de la superficie de la muestra. Entrega una imagen ampliada de hasta 200.000 veces y no es necesario cortar el objeto en capas para observarlo. Produce imágenes tridimensionales.

22 Entrevista al ingeniero bioquímico Jaime Emeres. 2 de febrero del 2012. 
FIGURA 6A

DOS APROXIMACIONES DE 7100 U.M. Y 7500 U.M., RESPECTIVAMENTE, DE LA ASTILLA
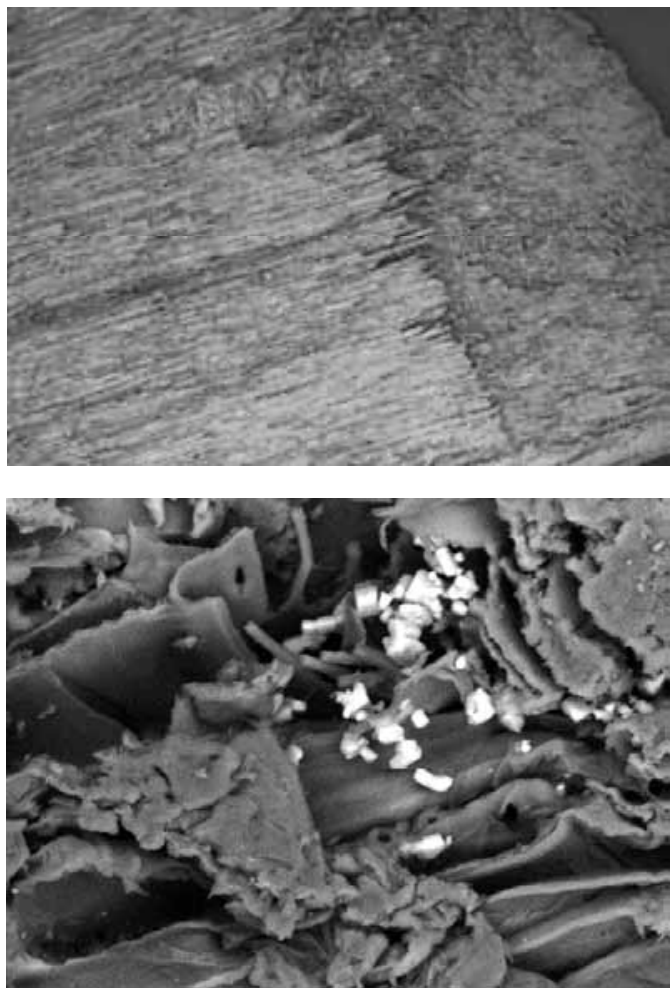

A partir de lo anterior se descartaron los tejidos de caña. Se concentraron las probabilidades en maderas de especies arbóreas. Las consideradas fueron la Ayawaya $a^{23}$, la mara ${ }^{24}$, el $\operatorname{tarco}^{25}$ y el paquío ${ }^{26}$. Esta última se constituyó en la mejor probabilidad. El paquío es un gigantesco árbol que crece en la Amazonía

23 Arbusto del altiplano sur boliviano. Nombre científico: Adesmia polyphila.

24 Nombre científico: Swietenia macrophylla. Su madera es dura, veteada, de color café rojizo. Su corteza externa es fisurada, escamosa, de color pardo grisácea y la corteza interna es rojiza y fibrosa. $\mathrm{Su}$ grosor es de 10 a $25 \mathrm{~mm}$ en promedio. Su corteza tiene alto contenido de tanino.

25 Nombre científico: Jacaranda mimosifolia D. Don. De color blanco/amarillo. Posee una médula que orienta con facilidad el perforado de la rama escogida. La perforación de la mara es más compleja que la del tarco. El árbol crece al borde de los ríos. Se encuentra en Potosí y Chuquisaca.

26 Paquío, nombre científico: Hymenaea courbaril. Familia: Leguminosae (Caesalpinaceae). Distribución: La Paz, Cochabamba, Pando, Beni y Santa Cruz en Bolivia. Generalidades: alcanza alturas de 27 a 40 metros con un diámetro de $0,75 \mathrm{~m}$. El duramen es de color café rojizo uniforme, la albura es de café amarillento. Peso mediano, densidad promedio a 0,61 cuando se seca al $12 \%$ C.H. y aproximadamente 0,96 en estado verde. Durable respecto al ataque de hongos. 
boliviana. La madera del paquío es tan peculiar que es extremadamente densa y moldeable a la vez. Esto significa que se pueden modelar pequeños objetos con ella sin que se parta o se desgrane, pero, a la vez, es lo suficientemente blanda como para permitir perforaciones e intervenciones en ella. Esto fue un descubrimiento sorprendente, porque la mayor parte del tiempo se ha escrito que los aerófonos sudamericanos son todos de caña, hueso o cerámica. Probablemente esta sea la primera demostración científica de que sí existe una madera de antigüedad precolombina susceptible de ser utilizada para la fabricación de tan delicados instrumentos (ver Figuras $6 \mathrm{~b}$ y $6 \mathrm{c}$ ).

FIGURA 6B

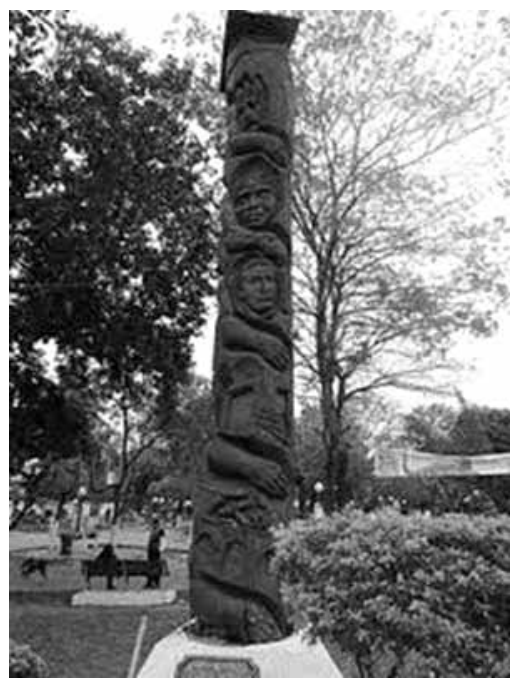

Paquío tallado en la plaza principal de Roboré, Bolivia.
FIGURA 6C

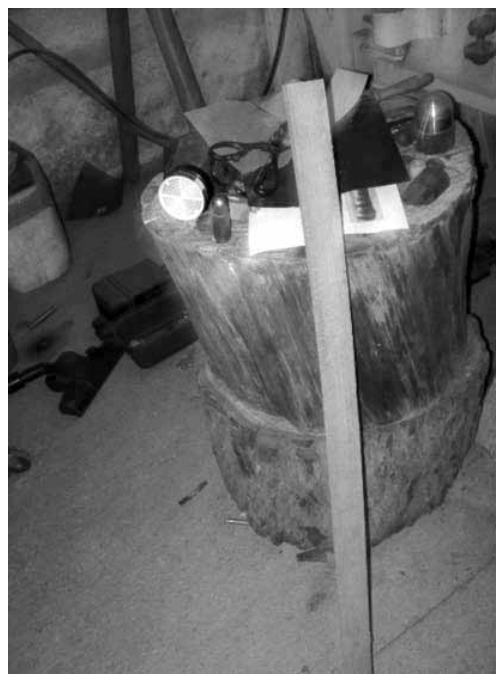

Trozo de madera de paquío en el proceso de reconstrucción de la flauta Tiwanaku.

Foto del autor.

Se ha demostrado que Tiwanaku se abasteció de materia prima en regiones amazónicas donde crecía el paquío. Berenguer (2000) menciona a las colonias del húmedo oriente, pues Tiwanaku también se expandió hacia los valles de la vertiente oriental de los Andes, el valle de Cochabamba y sus alrededores, a más de $400 \mathrm{~km}$ al este y a una altura de $2600 \mathrm{~m}$, donde se realizaban proyectos agrícolas. Según Berenguer, "toda la zona era una estepa espinosa, poblada con altos árboles, molles, algarrobos, jacarandaes, alisos, jarcas y taras, así como diversas cactáceas. Sus ricos suelos, abundantes recursos hídricos y clima agradablemente templado, hacían de esta región una excelente zona maicera (...). Una variedad de otros artículos, especialmente de la jungla, interesaban también a los Señores del Lago Sagrado" (2000: 69) (ver Figuras 7a, 7b, 7c y 8). 


\section{FIGURA 7A}

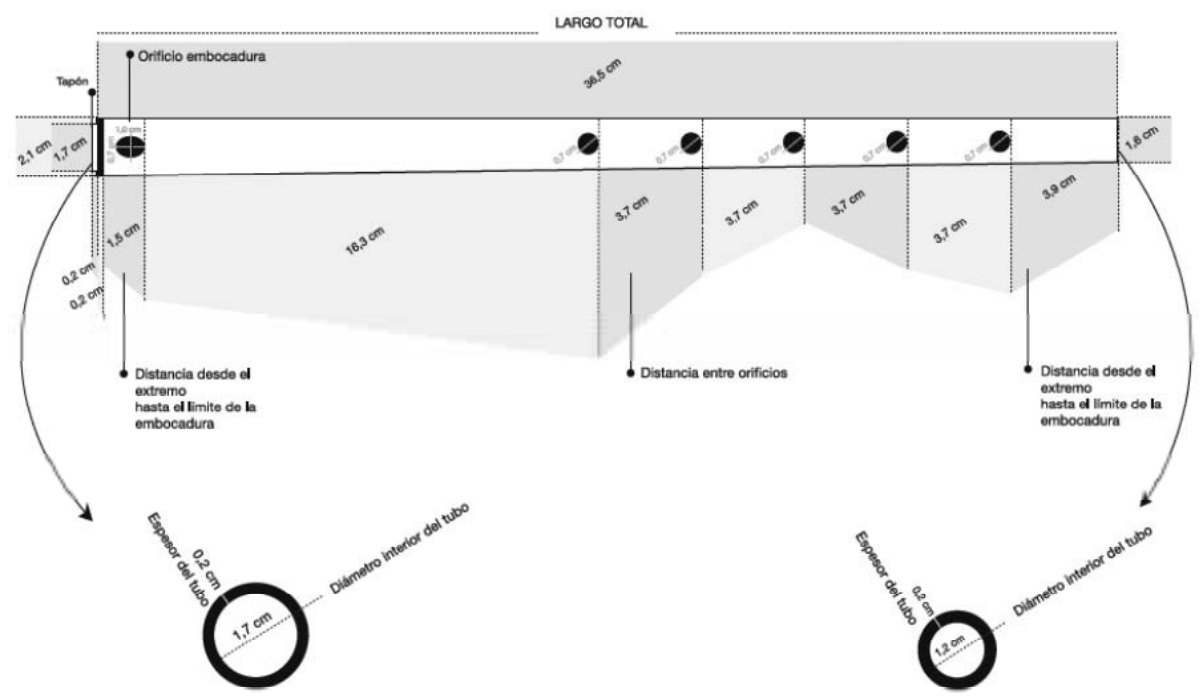

Plano para la reconstrucción de la flauta Tiwanaku²7

\section{FIGURA 7B}

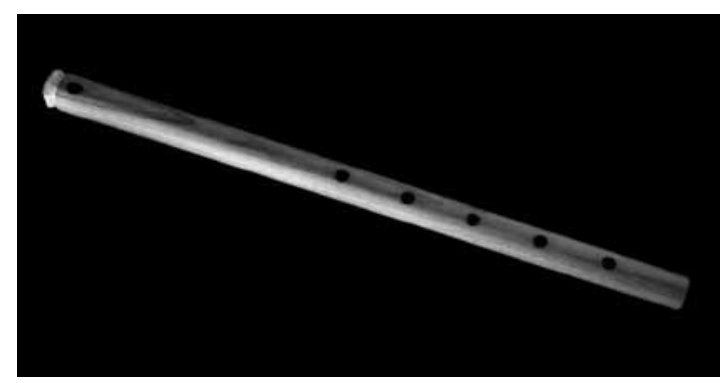

\section{FIGURA 7C}

Réplica de la flauta Tiwanaku terminada. Fotografía de María José Pérez.

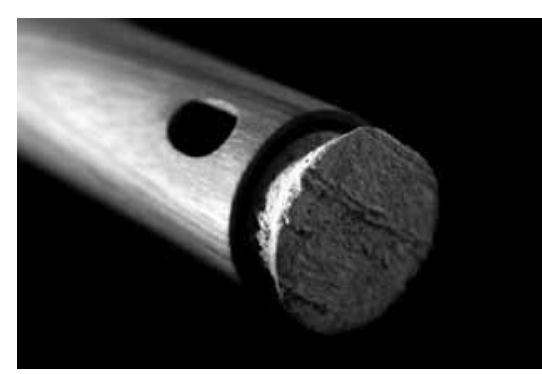

Detalle de la embocadura de la réplica. Fotografía de María José Pérez.

27 La flauta original fue dimensionada con un escalímetro, instrumento de alta precisión, del tipo "pie métrico digital metálico", de rangos 0-300 mm y 0-12 pulgadas. 


\section{FIGURA 8}

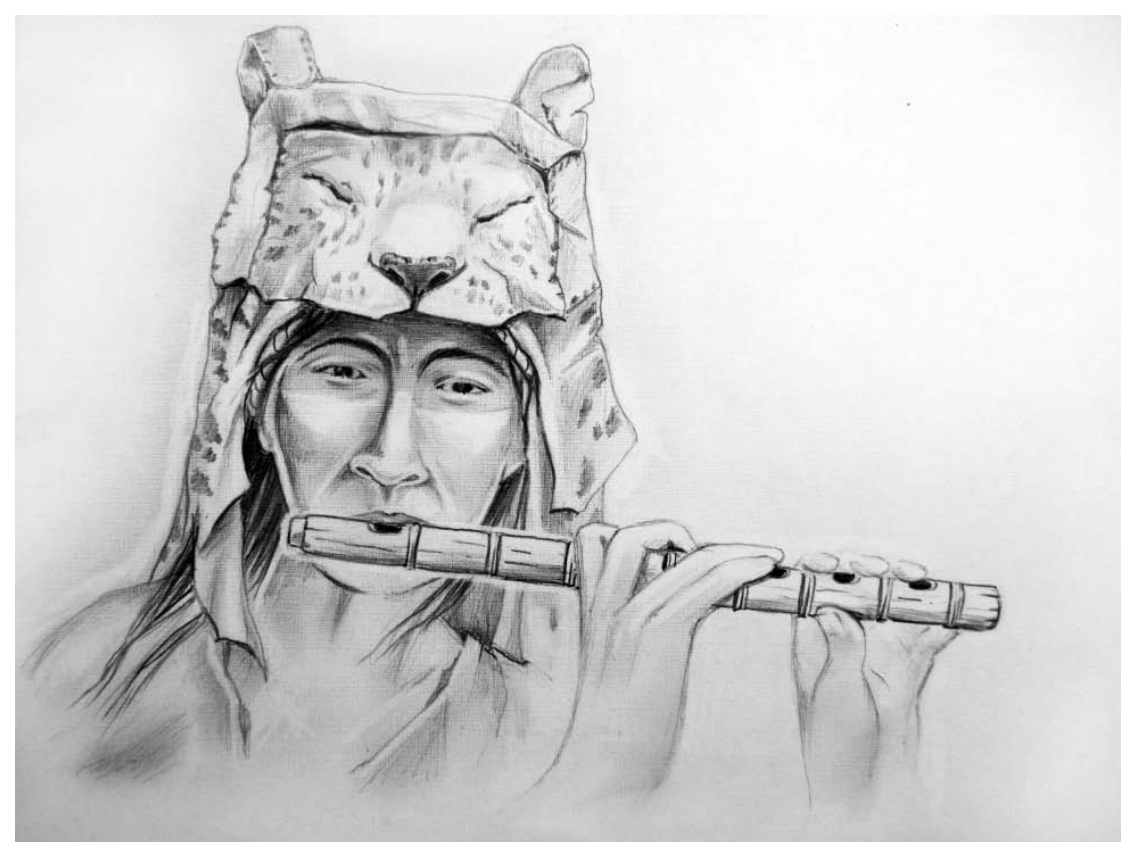

Representación de shamán ejecutando la flauta Tiwanaku. Dibujo de Claudia Valiente. El vestuario que aparece en la ilustración fue tomado del vestuario shamánico en exhibición en el Museo San Miguel de Azapa, Arica, Chile.

\section{IDIOLECTO SONORO DE LA FLAUTA TIWANAKU}

\subsection{Sistema escalar de la flauta Tiwanaku}

El sistema escalar de la flauta Tiwanaku reconstruida coincide con el sistema de la flauta originaria con una diferencia de semitono. Esta diferencia es en realidad menos que el semitono temperado, debido a que el La4 de la flauta original está afinado en $429 \mathrm{~Hz}$. Luego, la diferencia entre las dos primeras notas de ambas flautas es microtonal (ver Figura 9).

La modalidad hegemónica que se desprende de este sistema escalar es la pentafonía por tonos (es decir, por segundas mayores). Esto, porque el sonido Fa\#5 es tan débil como lo era el sonido Sol5 de la flauta Tiwanaku original. Ambos sonidos son posibles de extraer con la técnica de la hiperinsuflación. Por tanto, podemos colegir que, desde el punto de vista de la emisión natural del sonido, es la escala pentáfona por tonos la que predomina. Este sistema es conocido occidentalmente como "escala por tonos" (Días 1953) o "sistema B por tonos", según D’Harcourt (1990). Sin embargo, a diferencia de la escala por tonos universalmente conocida, 
que consta de seis sonidos (escala hexáfona), la escala por tonos de la flauta Tiwanaku es pentáfona, lo que es una diferencia importante respecto del patrón de seis sonidos universal. Tal como la flauta Tiwanaku originaria, posee una nota "modulatoria" que permite derivar al sistema pentáfono por tonos (La4). La diferencia de semitono entre el sistema escalar de la flauta original y la reconstruida obedece a factores naturales que afectan la densidad de la madera (la original de más/menos 15 siglos de antigüedad y la reconstruida de tejido que no tiene más de sesenta años).

\section{FIGURA 9}

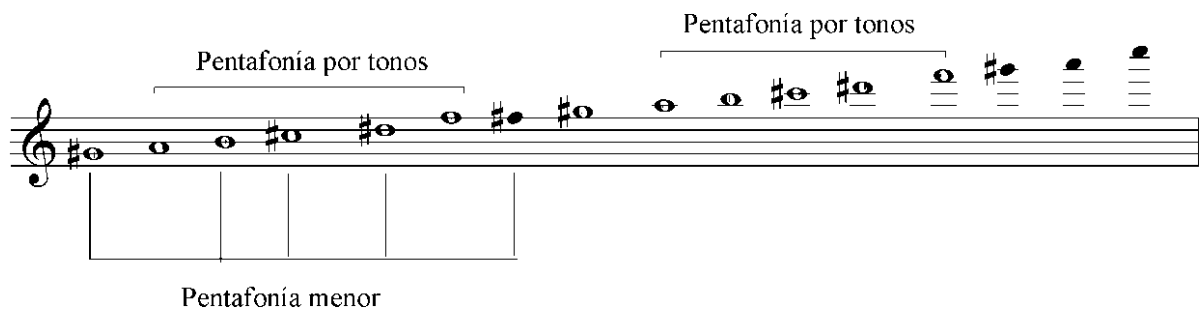

Evidentemente, el sistema escalar por tonos al no tener "intervalos de reposo" (semitonos) es el ideal para producir diseños melódicos tránsicos, porque su contorno jamás cierra o cadencia y porque cualquiera puede ser su nota de reposo o finalis. Esto favorece el continuum melódico que está al servicio de una inducción de estado tránsico. Este mismo rasgo "liso", o sin bordes del sistema por tonos, es lo que hace que sea poco propicia para músicas carnavalescas asociada a fiestas patronales, en las que el discurso de "eterno retorno" está estructurado en secuencias antifonales y vigorosamente pulsativas por la importancia del baile. Los diseños carnavalescos funcionan a base de fórmulas o secuencias repetitivas en las que la cadencia siempre se vuelve anacrusa de la repetición de la fórmula.

Es por eso que los sistemas escalares propicios para la inducción tránsica hayan tenido en el mundo precolombino un carácter ceremonial "privado" y restringido. El instrumental musical shamánico iba de la mano con todo un aparato ideológicoespiritual (Quispe 2008). El llegar a concebir una flauta traversa no era el objetivo. El objetivo era cómo podía servir el instrumento en el aparato ceremonial. La aparición y desaparición de este sistema escalar pentáfono por tonos (que es algo tan importante como el soporte instrumental que lo contiene) revela un cambio significativo dentro del sistema de la performática ritual Sur Andina: la pérdida gradual del shamanismo, y con él, la capacidad de ritualizar los espacios privados. En su reemplazo se impone el concepto de catarsis colectiva de las fiestas patronales. Si no fuera así, la flauta traversa de Tiwanaku no hubiera sido jamás reemplazada por el pífano travesero de las cofradías. 


\subsection{En busca del sistema escalar de la flauta Tiwanaku}

Es difícil rastrear la música de Tiwanaku hacia atrás en el tiempo. Más difícil aún resulta pesquisar el sistema escalar por tonos en una música predominantemente pentáfona. No obstante, disponemos de las fiestas patronales para intentar reconstruir el vínculo quebrado entre la sonoridad idiomática de la flauta reconstruida y su hipotética existencia en el pasado musical de Tiwanaku. En especial nos interesan aquellas fiestas patronales en las que la preceptiva estilística de los aerófonos ejecutados esté bajo la regulación aymara. Esto, porque las investigaciones actuales inducen a pensar que los pobladores de Tiwanaku eran aymara parlantes (Goldstein 2005; Berenguer 2000; Quispe 2008). Nos concentraremos en la fiesta de Saludos a los compadres ${ }^{28}$. El diseño melódico de esta fiesta tiene como rasgos pregnantes $^{29}$ los saltos de tercera mayor y menor, ascendentes y descendentes y pasajes menos prominentes por grados conjuntos, este último rasgo propio de melodías quechuas (Quispe 2008). La melodía Saludos a los compadres está ejecutada en la fiesta del mismo nombre con una quena Tiwanaku de registro malta, la que es ejecutada con una preceptiva estilística propia de la quena de la zona lacustre del Titikaka (Quispe 2008: 114) (ver Figuras 10 y 11).

\section{FIGURA 10 \\ SISTEMA ESCALAR QUENA TIWANAKU}

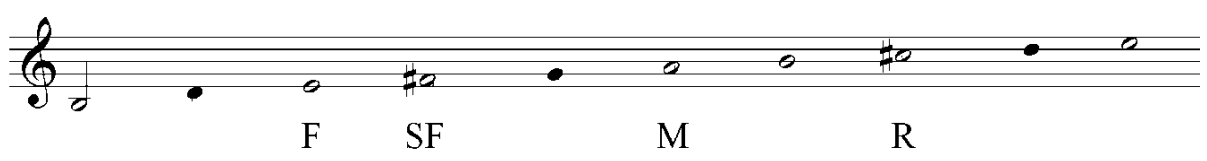

El sistema escalar de la quena Tiwanaku (F es finalis, SF es superfinalis, M es mediantey $\mathrm{R}$ es repercusa) refleja la jerarquía de sonidos que establece el diseño melódico pentafónico ${ }^{30}$.

28 Esta fiesta se celebra el 21 de abril en la comunidad Mollo Grande de la provincia de Muñecas, departamento de la Paz, Bolivia. A pesar de estar bajo el control de la comunidad quechua, la ejecución de las fórmulas melódicas rituales son de origen aymara proveniente del área lacustre de Tiwanaku. Por eso nos concentramos en los diseños melódicos de esta fiesta patronal en busca de rastrear la identidad musical de Tiwanaku. Debido a que Tiwanaku solo es reconocida por vestigios materiales, la música que hoy se le atribuye es la expresión musical aymara que se encuentra en el territorio de Tiwanaku.

29 "Pregnante" es un elemento musical que se vuelve demasiado prominente en relación con otros elementos que intervienen en el discurso musical.

30 Pentafonía de modo mayor según D’Harcourt (D’Harcourt 1990). Pentafonía mayor debido a que la estructura de tonos profunda del sistema escalar es Mi-Fa\#-La-Si-Do\#. Se denomina pentáfona mayor a aquella escala cuyo primer intervalo entre finalis y superfinalis (I y II grado) es de segunda mayor. La mayor jerarquía de los sonidos en el sistema escalar está representada por las redondas. Esta jerarquía se deriva del rol estructural que poseen estas notas en el diseño melódico de las secuencias ejecutadas por este instrumento. 
FIGURA 11

FÓRMULAS DE SALUDOS A LOS COMPADRES.

FIESTA RITUAL DE LA COMUNIDAD MOLLO GRANDE
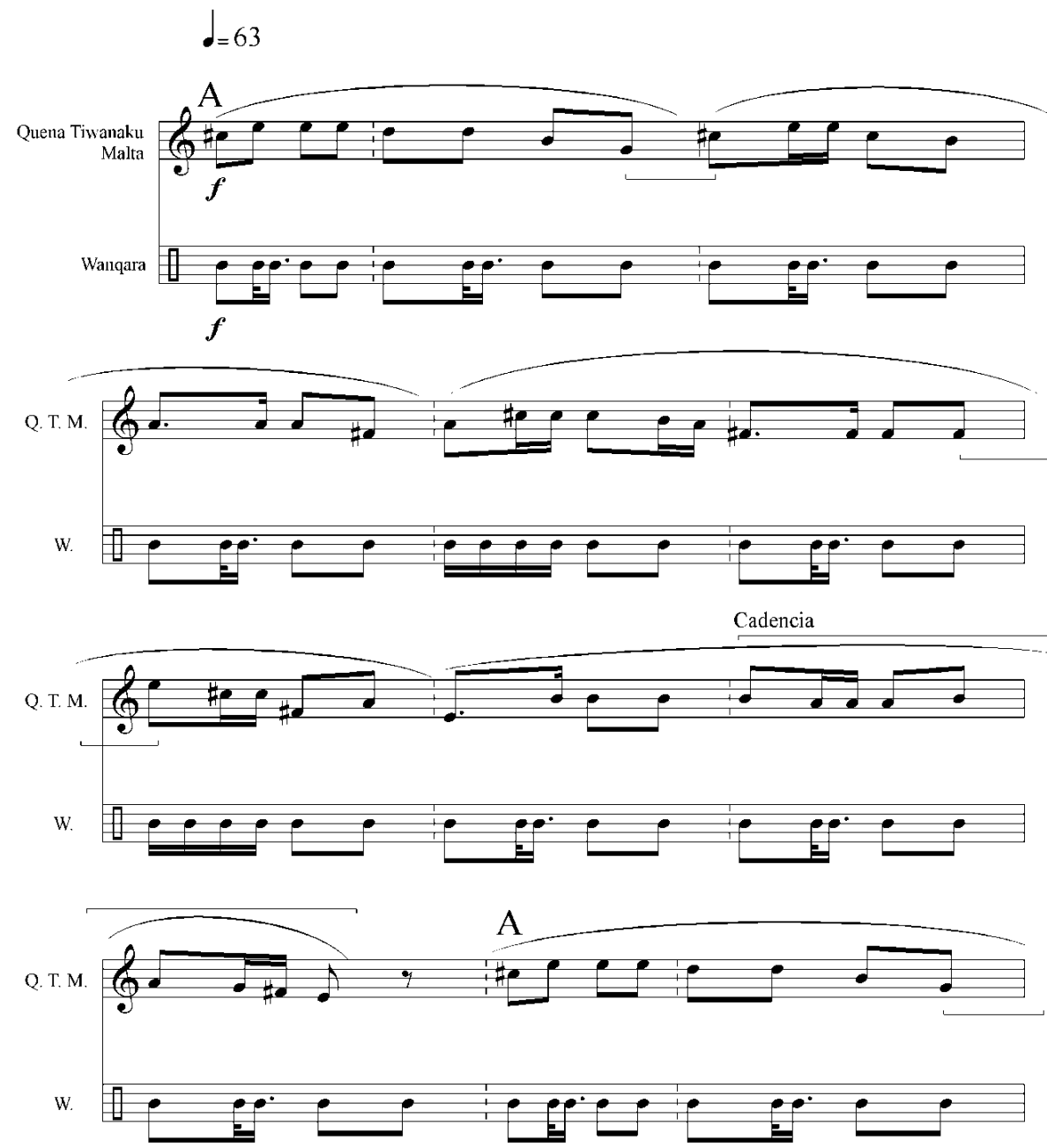
Q. T.

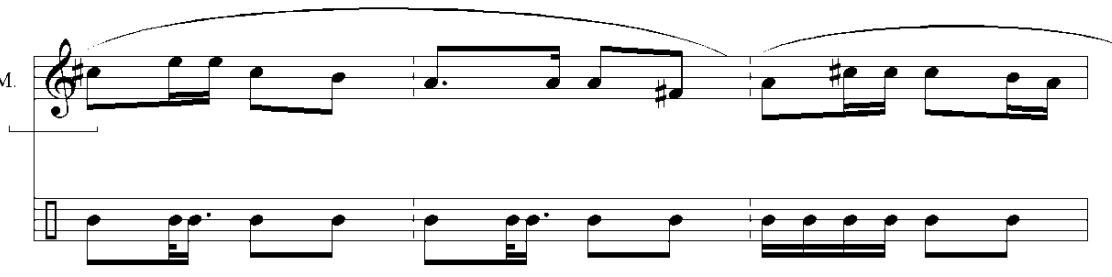

Q. T. M.

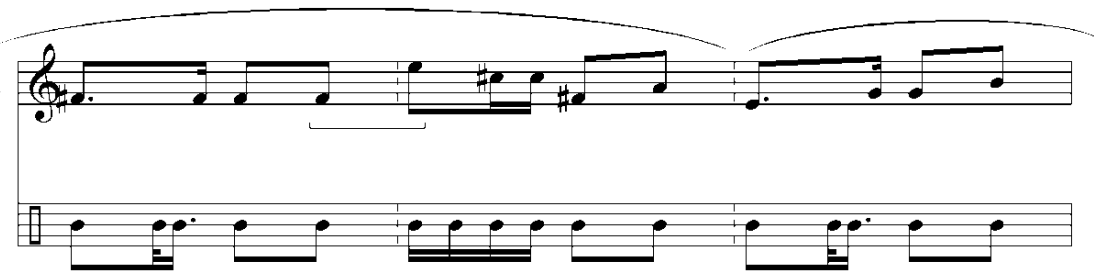

Cadencia

Q. T. M.

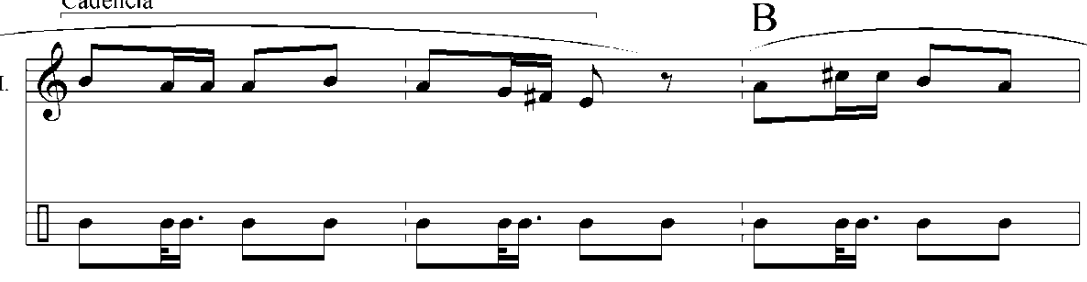

Q. T. M.

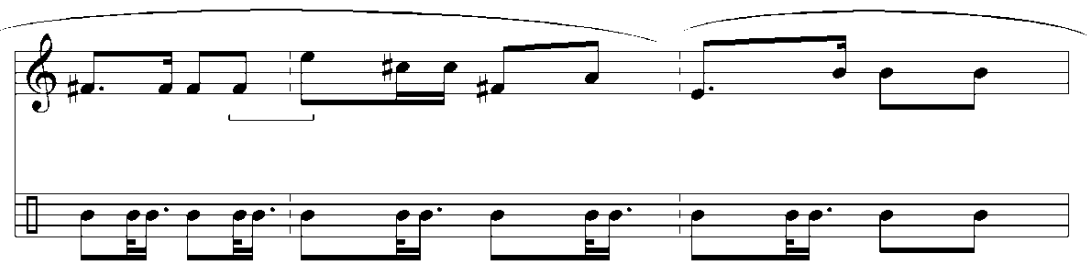

Cadencia

Q. T. M.

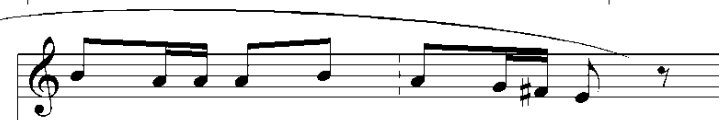

W.

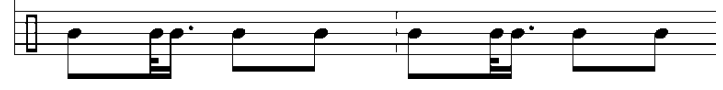

Performática registrada el 21 de abril del 2005 por el autor en la comunidad Mollo Grande, provincia de Muñecas, departamento de La Paz, Bolivia. Transcripción del autor. 


\subsection{Análisis neoschenkeriano de Saludos a los compadres}

Para estudiar la estructura tonal ${ }^{31}$ de Saludos a los compadres recurro a una escuela de análisis reduccionista que me parece la más apropiada para revelar las implicancias modales de las secuencias de la Figura 11. A continuación se presentará una carta gráfica neoschenkeriana en la preceptiva de Wallace Berry ${ }^{32}$. Es preciso subrayar que las peculiaridades melódicas de una música son reconvertidas por este tipo de análisis a un código de jerarquías en las que símbolos rítmicos convencionales pasan a cumplir un rol no convencional: el rol de representar jerarquías estructurales de los sonidos (Berry 1989). La jerarquía se mide ahora por una combinación de consideraciones paramétricas teniendo como prioridad el rol de una nota dentro de un sistema escalar y, en menor jerarquía, las variables del ritmo y el timbre.

En la carta gráfica siguiente (middleground en términos de Berry, que alude a un nivel de reducción intermedia) de las secuencias Saludos a los compadres se establecen tres niveles de jerarquía por medio de los valores diferentes de las cabezas de las notas (blancas para las notas de mayor jerarquía estructural y que coinciden con los sonidos principales del modo de las secuencias; negras para aquellas notas que sostienen el transcurso del discurso y que poseen menor peso dentro de la jerarquía modal, por lo tanto, poseen menor prolongación en el espacio-tiempo). Se representan niveles menores de jerarquía con notas negras carentes de plicas para sonidos auxiliares y para células de transición hacia los eventos que sostienen el discurso ${ }^{33}$. Las plicas unidas de corcheas de cabeza blanca describen la proyección en el tiempo y en el espacio de la modalidad que rige a la secuencia (ver Figura 12a).

La Figura 12 nos permite captar rápidamente la naturaleza de las dos secuencias, A y B, de la melodía ritual Saludos a los compadres. Podemos apreciar el rol estructural profundo de las notas Mi4-Fa\#4-La4-Si4-Do\#5-Mi5 que sostienen el esqueleto de las dos fórmulas. También podemos observar que, insertada en esta estructura fundamental, se encuentran ciertas relaciones interválicas que solo poseen valor superficial en la estructura antes mencionada, pero que arrojan importantes luces respecto de otro sistema escalar que parece transparentarse bajo el predominante. En especial, me refiero a las interválicas Si4-Sol4-Do\#5 y

31 Tonal se refiere aquí a tono o nota y no a tonalidad. El término surgió en la escuela revisionista de Schenker (principalmente Salzer, Forte y Berry) y continúa usándose hasta hoy.

32 En esta carta se aprecian todos los códigos simbólicos de Schenker, pero en clave revisionista, más cercana a la escuela de Berry y de Forte. Las diferencias más importantes entre estas escuelas norteamericanas y la teoría original de Schenker son la superación del concepto de triada como el único elemento que se proyecta en el tiempo, la extensión del análisis a sistemas armónicos no tonales y el descarte del concepto apriorístico de la estructura fundamental en dos partes. Por cierto, el uso de esquemas gráficos no excluye el empleo de descripciones verbales. El comentario analítico que se desprende de la imagen no invalida al mismo, sino que permite interpretarlo y, al hacerlo, se devela la información esencial que se espera obtener de la música. El poder de la inmediatez de la imagen frente a la excesiva descripción de palabras era el objetivo profundo de Schenker. El gráfico es una representación material inmediata del espacio-tiempo del discurso musical.

33 Estas células de transición podrían contener notas de alto valor estructural, pero que, en las células, cumplen un rol inferior en la dinámica espacio-temporal (Berry 1989). 
FIGURA 12A

CARTA GRÁFICA MIDDLEGROUND DE SALUDOS A LOS COMPADRES
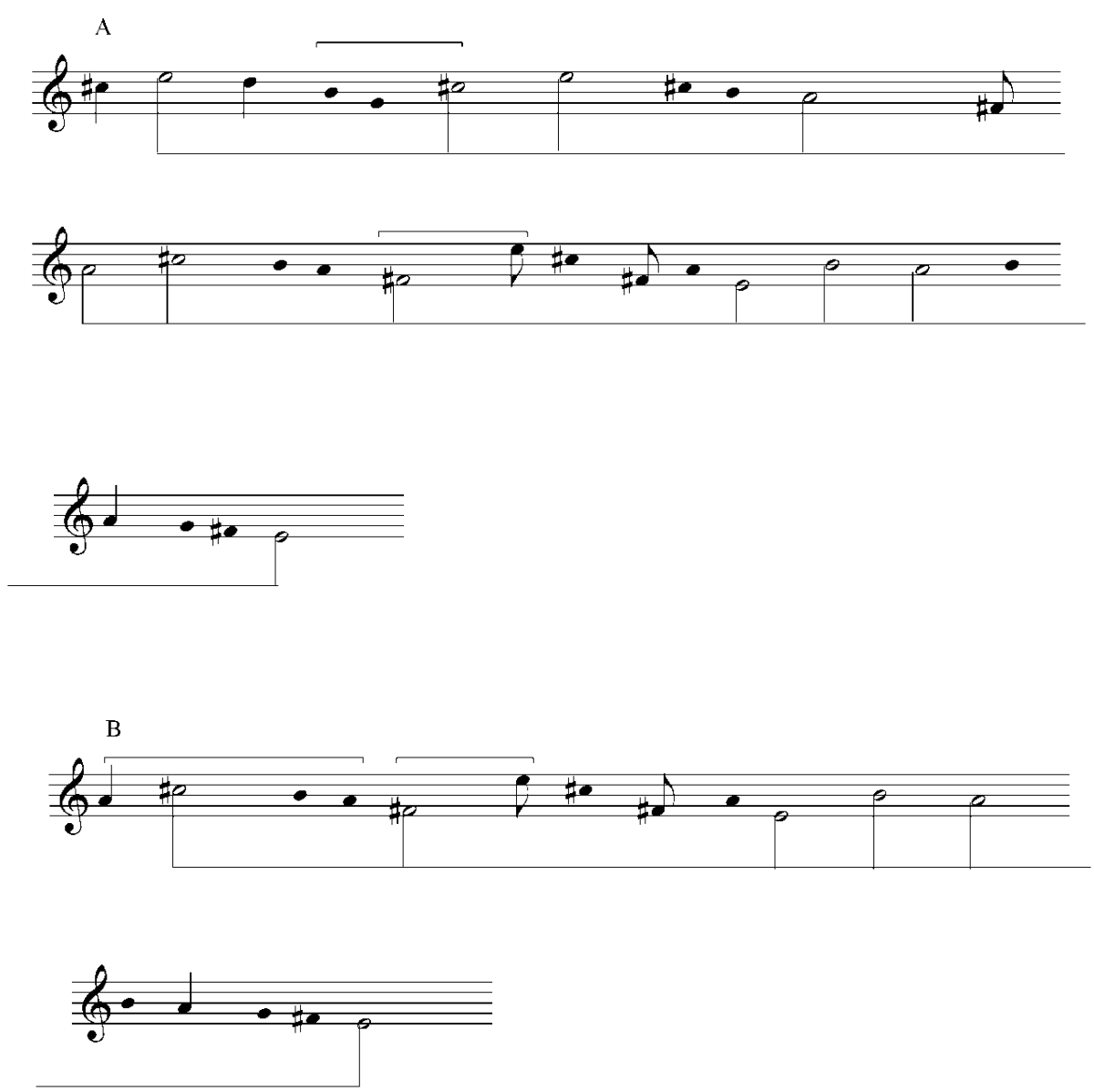

Fa\#4-Mi5 (marcadas en corchetes en la secuencia A) y las interválicas La4-Do\#5Si4-La4 y Fa\#4-Mi5 (marcadas en corchetes en la secuencia B). Estos intervalos ${ }^{34}$ rompen completamente la sonoridad pentáfona menor característica de la actual música carnavalesca del área Sur Andina. En especial, los intervalos de tritono (Sol4-Do\#5) y séptima menor (Fa\#4-Mi5) no corresponden en absoluto a la interválica de los diseños melódicos pentáfonos. Destruyen absolutamente su sonoridad característica y, por sobre todo, la identidad intrínseca del sistema pentáfono menor de raíz quechua. Estos intervalos, en el diseño melódico de Saludos a los

34 También marcados con corchetes en la Figura 11. 
compadres, son muy probablemente "residuos" del sistema pentáfono por tonos que aún subyacen en las fórmulas solísticas rituales de instrumentos ejecutados en la preceptiva Tiwanaku ${ }^{35}$. La pentafonía menor de raíz quechua no podría generar esos manierismos melódicos. Solo los sistemas escalares por tonos (hexáfonos o pentáfonos) pueden producirlo tal como lo muestra la Figura 12b.

FIGURA 12B

INTERVALOS IDENTITARIOS DEL SISTEMA ESCALAR POR TONOS
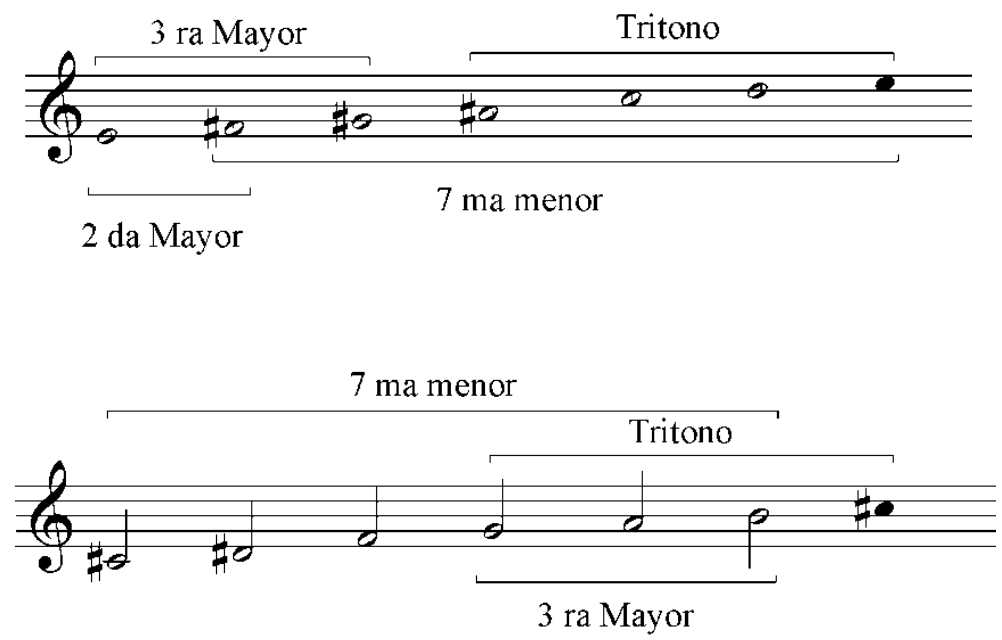

\section{PÍFANO TRAVESERO POSTCOLOMBINO}

Durante toda la Edad Media, el Renacimiento y los comienzos del período Barroco, el pífano travesero fue más que nada un instrumento militar. Este modelo de

35 A diferencia de la mayoría de las secuencias rituales adscritas a fiestas patronales, en donde predominan los conjuntos instrumentales llamados "tropa" y las sonoridades de quintas paralelas, la secuencia Saludos a los compadres se ejecuta con una sola melodía (lo que implica un rol solista del ejecutante del aerófono). Este rasgo suele ser vinculado al "estilo antiguo Tiwanaku", caracterizado por los D’Harcourt como "música exclusivamente monódica” (D’Harcourt 1990). Para ellos, el discurso melódico monódico de Tiwanaku es representativo de su etapa musical más remota (antes de las octavas paralelas de las tarqueadas de la zona del lago Titikaka) y se puede encontrar hoy también en el sistema organológico-cultural Wiñay Siku Tutiris. El diseño melódico de Saludos a los compadres, basado en una irregular escala pentáfona mayor habría sido una derivación del sistema escalar por tonos, debido a que ambos sistemas escalares privilegian las segundas mayores (Persichetti 1985). 
pífano, para algunos, antepasado del flautín o piccolo ${ }^{36}$, se puede observar en la siguiente Figura 13a.

FIGURA 13A

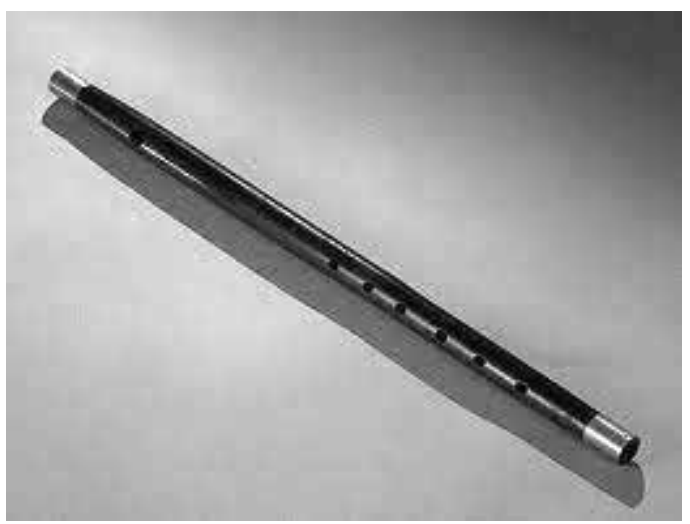

Pífano militar renacentista. Exposición Casa de América, Madrid.

Fotografía del autor.

El sistema de escala que regía a este instrumento presentaba diferencias regionales en Europa. No obstante, al carecer de llaves para producir alteraciones ${ }^{37}$, lo común a todos los modelos en Alemania, España y Suiza era un sistema de escala diatónica como el señalado en la Figura 13b.

\section{FIGURA 13B}

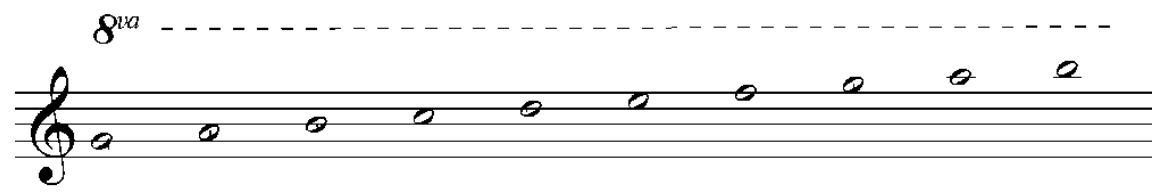

36 Para Felipe Pedrell, el pífano fue un instrumento esencialmente militar que representa una especie y una línea evolutiva independiente. En un instante del Renacimiento el pífano y el flautín coexistieron, aunque el último proviene de la familia de las flautas traversas y no debiera ser confundido con el primero.

37 La primera llave que se le introdujo al pífano militar fue la llave del Re\# (Pedrell 1901). 
La nota finalis (o de reposo) podía estar en cualquiera de estas notas. Eso dependía de la melodía que se ejecutaba. Estos diseños melódicos eran exclusivamente modales. La canción militar medieval sufrió un proceso de "himnización" hasta convertirse en el Renacimiento en fórmulas sólidamente establecidas y basadas en sistemas de escalas de la modalidad renacentista tal como fueron usadas en Europa ${ }^{38}$. Lo importante es que el pífano no podía ejecutar estos modos transportados (modos fictos o transpuestos), por lo que debían ser ejecutados diatónicamente. Este fue el instrumento que llegó a América con las huestes españolas y, en el ocaso de los imperios meso y sudamericano, fue parcialmente asimilado por un modelo de pífano que responde a distintos nombres según la región donde alcanzó a utilizarse ${ }^{39}$.

La flauta traversa conocida como phalahuito o simplemente phala, es una adaptación del pífano traverso militar traído por los españoles (ver nota 39). El phalahuito hecho de caña y de madera, con seis agujeros y de dos tamaños (mediano y pequeño) aún se usa acompañado del redoble del wankara ${ }^{40}$ para llevar ofrendas a los templos u obsequios a los que celebran bodas o realizan alguna fiesta de importancia local. Debido a que no es un instrumento de potencia sonora, solo en "tropa" ${ }^{11}$ participa de las fiestas patronales (ver Figura 14a).

38 Específicamente es el caso del dorio, frigio, lidio, mixolidio, eolio y jonio en sus modos plagales y auténticos. Estos nombres no se corresponden con la terminología griega, pero fueron usados conservando sus finalis originarias y, algunas veces, manteniendo y agregando nuevas repercusas al modo (caso del frigio, mixolidio y eolio).

39 En tiempos postcolombinos el instrumento se denominó de diversas maneras. En Ecuador se llamó flauta de Carrizo. La tunda ecuatoriana también se identificó con las características del pífano travesero de seis agujeros. En el norte de Chile (Arica y Atacama) como en Bolivia y Perú, el pífano recibió el nombre de phala o phalahuito. El phala pasó en la Colonia a llamarse "pífano" en las fiestas patronales de Bolivia. El pífano también está presente en el sur de Chile, conocido como pinkulwe en el área cultural mapuche. El pinkulwe es llamado pitucavoe por el cronista Luys de Valdivia (15811606), el que define como "un pífano", lo que da señas de su morfología y características sonoras en el siglo XVI (Valdivia 1606: s/n). El pinkulwe no puede ser rastreado antes de la llegada de los españoles. El pinkulwe de la Colonia posee un sistema escalar pentáfono, completamente ajeno a los sistemas escalares mapuches caracterizados por tetracordios de terceras menores sucesivas (trutruca, piloilo, sonoridad resultante de dúos de pifülkas, canto de machi, etc.), lo que es muy revelador de la influencia inca en su manufactura. El inca, a su vez, utilizaba un phala que no se aparta del canon pífano militar español. Por lo tanto podemos colegir que el modelo introducido por el inca en la cultura mapuche fue un prototipo ya adaptado del pífano militar europeo.

40 Tambor de posible origen prehispánico. Está compuesto de membranas de cuero de chivo adheridas a aros, los que a su vez están reforzados por más aros entrelazados. Se toca con dos pequeños mazos. Su diámetro estándar se sitúa en un rango de $55 \mathrm{~cm}$ a $57 \mathrm{~cm}$.

41 Modo de congregarse de los instrumentos en los carnavales del área de los Andes Centrales y Sur Andina. Los instrumentos se agrupan por especie y familia. La sonoridad colectiva es el modo natural y predominante de ejecución en las fiestas patronales. 
FIGURA 14A

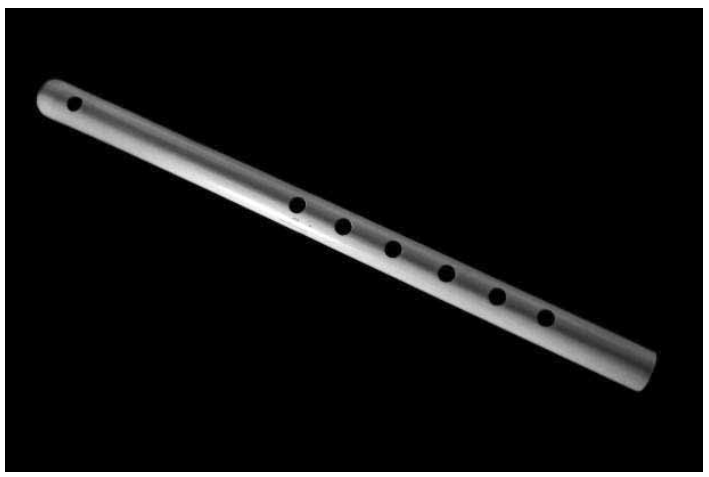

Fotografía de phalahuito fabricado en La Paz.

Tomada el 24 de febrero del 2012 por María José Pérez.

Su sistema escalar es muy relevador de su origen (ver Figura 14b).

FIGURA 14B

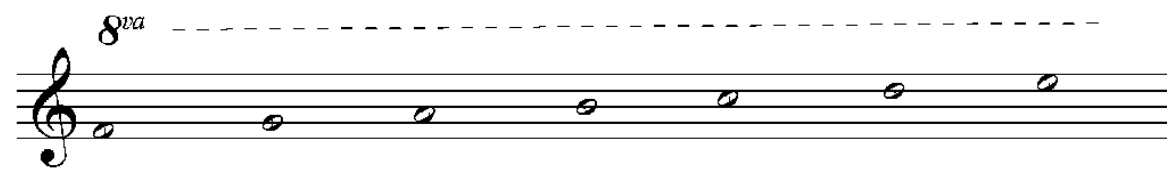

Este sistema escalar del registro malta del phala o phalahuito $(40,6 \mathrm{~cm})$, fabricado en caña, mantiene una modalidad idiomática diatónica. No podía ser de otra forma, ya que el número de agujeros del instrumento, su diámetro (igual para cada agujero) y el patrón de distancia regular entre agujeros de digitación determina su diatonismo.

Este sistema escalar diatónico es adaptado al sistema escalar pentáfono, de raíz quechua, que rige a la mayoría de las fiestas patronales en tiempos presentes (ver Figura 14c).

FIGURA 14C

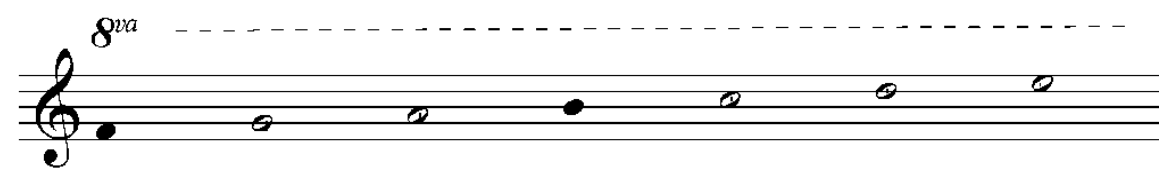


Las notas en negras son omitidas durante el transcurso de fiestas tales como el ritual Saludos a los compadres de Mollo Grande (21 de abril) y la fiesta de San Lorenzo del cantón Ayata de la comunidad Milliraya en la provincia de Muñecas (10 de agosto), ambas en Bolivia, en las que conviven la población aymara con la quechua (Quispe 2008: 109 y 116). Lo importante es que, en ambas fiestas, la modalidad de ejecución Tiwanaku pervive en los instrumentos. Ellos están adscritos a un sistema cultural complejo desde tiempos prehispánicos. Gracias a esta interdependencia cultura-religión-instrumentación, la etnomusicología tiene una oportunidad de reconstruir vínculos perdidos.

\section{CONCLUSIONES}

La hipótesis que se ha intentado demostrar en este artículo es que la flauta traversa de Tiwanaku es la única genuina flauta traversa precolombina sudamericana conservada en condiciones de estudio. Los actuales pífanos sudamericanos en uso en fiestas patronales derivan del pífano militar europeo y son una adaptación. No encontramos en la museología sudamericana un tipo de flauta traversa que rompa el canon del pífano militar europeo. El pífano o phalahuita/phala es un instrumento postcolombino, que las comunidades quechua y aymara adoptaron como propio. No obstante, es una adaptación del pífano europeo, el que es una pequeña flauta travesera de seis a ocho agujeros que se usaba principalmente en bandas militares. El pífano sudamericano se usa hoy en las cofradías de religiosidad popular y conserva todos los rasgos del pífano europeo. Tiene principalmente seis agujeros de igual diámetro y a una distancia regular unos de otros, es un aerófono de tipo travesero o traverso, de dimensiones pequeñas (aprox. 40,6 cm a $46,30 \mathrm{~cm}$ ) y su única diferencia con el modelo europeo es que está hecho de caña, llamada toq' oro en quechua.

La flauta traversa que el autor encontró en el MASPA (Chile) es un aerófono travesero pequeño, de exactos $36,5 \mathrm{~cm}$, de forma cónica, abierto en el extremo inferior y cerrado en el superior. Contra todos los pronósticos, el análisis de microscopia de barrido reveló que está hecha de madera, en especial de la madera proveniente de un árbol llamado paquío. La datación de la flauta fue obtenida en parte por los registros de carbono 14 efectuados en el gentilario de Coyo 1 por Oakland en 1992 y, en parte, por el análisis de contexto cultural ceramológico. En la tumba donde el padre Le Paige la encontró, había además un tipo de cerámica negra semipulida cuyo origen es Tiwanaku en la banda cronológica 500-900 d.C. Significa que la producción y la ideofactura de este tipo de cerámica abarca esa banda de tiempo y coincide con el período de esplendor de la cultura Tiwanaku, durante la época de mayor expansión del imperio.

La investigación ha demostrado que la flauta fue usada por un shamán y que su funcionalidad era la inducción tránsica.

Otra importante conclusión de este estudio es que la flauta Tiwanaku comporta un sistema escalar pentáfono por tonos, sistema actualmente desaparecido de la música ritual colectiva del área Andes Centrales y Sur Andina. 
Aparentemente hubo una directa relación entre la música shamánica y la modalidad por tonos. Esto debido a que, aun hoy, los modos de ejecución y la sonoridad de un aerófono están específicamente determinados por el aparato cultural al cual pertenece.

Respecto de la pregunta de por qué no existe este modelo de flauta en las actuales fiestas patronales, las razones son multifactoriales:

a) Era un instrumento pequeño, sin volumen sonoro prominente. Luego no sirve para situaciones carnavalescas.

b) Su fabricación es costosa. El tipo de madera que debe usarse y las diminutas dimensiones de los agujeros lo vuelven incluso hoy un objeto complejo de producir.

c) La actividad shamánica fue disminuyendo con posterioridad al año 900 d.C. El decaimiento del imperio Tiwanaku debilitó su influencia cultural en el oasis de San Pedro y, con ello, se perdieron las prácticas shamánicas de una religión compleja.

Solo se conserva un ejemplar de este tipo de flauta traversa de cinco agujeros en Sudamérica. No es improbable que en Bolivia exista algún ejemplar, pero no se ha podido detectar su existencia en museos y colecciones privadas. La praxis ritual en Bolivia está tan viva, que su población trasciende la museología para privilegiar el despliegue vigente de sus instrumentos rituales. Es indudable de que los sikus, las quenas y las tarkas poseen la suficiente fuerza como para seguir siendo instrumentos de uso colectivo (tropa) y socialmente vigentes. Es comprensible de que la gente no habría de interesarse por un instrumento que solo tuvo utilidad en el espacio privado y con el objeto de obtener una sanación inducida.

La conclusión final es que la cultura Tiwanaku fue capaz de desarrollar sus propios cánones organológicos, algunos, como este prototipo de flauta traversa, ¡varios siglos antes de que se estableciera industrialmente en Europa! Por siglos se ha hablado de la dependencia de Latinoamérica de los cánones europeos en lo que respecta a manufacturas e ideofacturas. La flauta traversa de Tiwanaku contradice una vez más esa visión.

Por último, este trabajo abre líneas de investigación futuras: la eventual existencia o inexistencia de un pífano travesero precolombino mesoamericano que contradiga el canon del pífano europeo. Por extensión, si la anterior suposición llega a demostrarse en modo negativo, la flauta Tiwanaku podría considerarse como el único prototipo de flauta travesera surgido en el Nuevo Mundo conservado en condiciones de estudio. No es imposible (más bien es bastante probable) que otros modelos de flautas traversas hayan existido a lo largo de América antes de la llegada del español. Lo difícil es encontrar un ejemplar en condiciones científicamente verificables como lo es esta flauta de Tiwanaku. 


\section{REFERENCIAS BIBLIOGRÁFICAS}

Berenguer, José

1988 Los primeros americanos y sus descendientes. Santiago: Antártica S. A.

2000 Tiwanaku. Señores del Lago Sagrado. Santiago: Museo Chileno de Arte Precolombino.

2004 Caravanas, interacción y cambio en el Desierto de Atacama. Santiago: Sirawi Ediciones.

Berry, Wallace

1989 Musical Structure and Performance. New Haven: Yale University Press.

Bittmann, Bente, Lautaro Núñez, Gustavo Le Paige

1978 Cultura atacameña. Santiago de Chile: Departamento de Extensión Cultural, Ministerio de Educación.

BorRas, GERARD

2011 "Organología de la tarka en la zona circunlacustre del Titicaca", en Arnaud Gerard (editor). Diablos tentadores y pinkillus embriagadores. Estudios de antropología musical del carnaval en los Andes de Bolivia. Tomo 1. La Paz: Plural Editores, pp. 41-67.

D’Harcourt, Raoul, Marguerite D'Harcourt

1990 La música de los Inkas y su supervivencia. Lima: O.P.C de Perú.

Días, José

1953 Sistema musical incásico. La Paz: Editorial Universidad Mayor.

GÉrard, Arnaud

2011 "Tara y tarka. Un sonido, un instrumento y dos causas", en Arnaud Gerard (editor). Diablos tentadores y pinkillus embriagadores. Estudios de Antropología musical del carnaval en los Andes de Bolivia. Tomo 1. La Paz: Plural Editores, pp. 69-140.

Goldstein, Paul

2005 Andean Diaspora: The Tiwanaku Colonies and the Origins of the South America Empire. Gainesville: University of Florida Press.

Grebe, María Ester

1974 "Instrumentos musicales precolombinos de Chile", RMCh, XXVIII / 128 (octubrediciembre), pp. 5-55.

ISBELL, WILLIAM

2008 "Wari and Tiwanaku: International Identities in the Central Andean Middle Horizon", en Elaine Silverman y William Isbell (editores). Handbook of South American Archaeology. Nueva York: Springer, pp. 731-759.

Le Paige, Gustavo

1964 "El precerámico en la cordillera atacameña y los cementerios del período Agro-Alfarero de San Pedro de Atacama”, Anales de la Universidad del Norte, $\mathrm{N}^{\circ} 3$. Antofagasta, pp. 96-127.

Llagostera, Agustín

2011 Los antiguos habitantes del Salar de Atacama. Santiago: Turismo-Chile Editores.

Llagostera, Agustín, María Antonietta Costa

1999 "Patrones de asentamiento en la época agroalfarera de San Pedro de Atacama (norte de Chile), Estudios Atacameños, vol. 17, pp. 175-206. 


\section{NORDENSKIÖLD, ERLAND}

1924 TheEthnography of South-America as seen from the Mojos in Bolivia. Göteborg: Comparative Ethnographical Studies.

NúÑEz, Lautaro

2007 Vida y cultura en el Oasis de San Pedro de Atacama. Santiago: Editorial Universitaria.

OAKLAND, AMY

1992 "Textiles and Ethnicity: Tiwanaku in San Pedro de Atacama, North of Chile", Latinomerican Antiquity III/ 4, pp. 316-340.

Orellana, Mario

1986 "Cultura de San Pedro de Atacama y sus relaciones con la civilización de Tiwanaku", Prehistóricas, $\mathrm{N}^{\mathrm{o}}$ 1, pp. 29-38.

Pedrell, Felipe

1901 Emporio científico e histórico de organografía musical antigua española. Barcelona: Valls-Barcelona.

Pérez de Arce, José

1982 La música en el arte precolombino. Catálogo de exposición. Santiago de Chile: Museo Chileno de Arte Precolombino.

Persichetti, Vincent

1985 Armonía del siglo XX. Alicia Santos Santos (traductora). Madrid: Real Musical.

Quispe, Filemón

2008 La Quena Mollo. Supervivencia y persistencia de música y danza tradicional andina. La Paz: Plural Editores.

TARRAgó, MYriam

1989 Contribución al conocimiento arqueológico de las poblaciones de los oasis de San Pedro de Atacama en relación con los otros pueblos puneños, en especial, el sector septentrional del Valle Calchaquí. Tesis para optar al grado de Doctor en Historia, especialidad Antropología. Rosario, Argentina: Universidad Nacional de Rosario, Facultad de Humanidades y Artes.

VALDIVIA, LUYS DE

1887 Arte y gramática general de la lengua que corre en todo el Reyno de Chile, con un Vocabulario, y Confessionario. Edición facsimilar por Julio Platzmann. Leipzig: B. G. Teubner. 